\title{
THE CONNACHTA OF TÁIN BÓ CÚAILNGE
}

\author{
ROMANAS BULATOVAS
}

National University of Ireland, Maynooth

\begin{abstract}
Advance in archaeology in the latter half of the 20th century rekindled interest in Táin Bó Cúailnge as a historical source and put the question of real-life identities of its main protagonists back on agenda. Despite the existing orthodoxy that the saga reflects fifth-century warfare between the southern Uí Néill and the Ulaid, some researchers continue questioning the role of the southern Uí Néill as well as the dates assigned to the events of the tale. In this article it is argued that the Connachta of the saga were more likely to be the northern Uí Néill. Furthermore, genealogical link between the two branches of the Uí Néill is put in doubt. Finally, it is suggested that the events of the Táin took place almost 200 years later than commonly believed.
\end{abstract}

Keywords: The cattle-raid of Cooley, the Uí Néill dynasty, early medieval Ireland.

\subsection{Preliminary Remarks}

Since T. F. O'Rahilly's mythological approach had fallen out of favour, it became received wisdom that the Táin contains a genuine memory of warfare between Connaught and Ulster. However, researchers rarely agree which of the finer details preserved in the saga are historically accurate, most importantly the timeframe of the events the text refers to and the identities of warring factions.

In a broad survey of current consensus concerning the antiquity of the Táin Ruairí Ó hUiginn presented several competing schools of thought (Ó hUiginn 1992: 32-33). Firstly, regarding the timeframe he endorsed ('has been accepted by many scholars') Jackson's conclusions who famously had considered Irish sagas a window on Iron Age society. Such authorities as David Greene and Cecile O'Rahilly were invoked to strengthen the point. It was also implied that James 
Carney's dissenting position was 'controversial'. Secondly, turning to the cast of characters Ó hUiginn mentioned briefly O'Rahilly's myth-driven beliefs. Then he proceeded to signal the dichotomy between an opinion represented by Carney and, in his words, 'the traditional view' exemplified by Eoin MacNeill and Francis J. Byrne. According to him Carney advocated that the Connachta of the saga should be construed as a midland dynasty hailing from the territory around Tara. On the other hand, 'the traditional view' supposedly holds that the Connachta waged the war 'from a base at Crúachnu in Roscommon'. As a side note it should be emphasized that despite considerable differences between their respective views, both Carney and Byrne converged on very similar dating for the warfare in question, namely the fifth-sixth century A.D.

The author of the survey himself does not seem to subscribe to either of the last two stances. Even having cited crushing linguistic and archaeological arguments against prehistoric dating, in the end he reverts to Jackson's position again (Ó hUiginn 1992: 52-53, 55):

The very subject of much of the Ulster Cycle, the conflict between the Connachta and the Ulaid, belongs to the prehistoric period [...] Jackson's assertion that the Ulster Cycle affords us an insight into pre-Christian Ireland is in a sense true [...].

This opinion is somewhat surprising since it seems to represent a major reversal for the scholar. Just a couple of years previously he remarked (Ó hUiginn 1990: $5-6)$ :

The political development which brought this about was, of course, the rise of the Uí Néill dynasty, a development which most probably took place in the $5^{\text {th }}$ century A.D. [...] Many would hold that the origin of the Ulster Cycle of tales derives from the early stages of that conflict, when the Uí Néill were first pressing northwards.

Unfortunately, the author did not express his personal arguments in favour or against given position in either of these contributions. Hence, it remains obscure why he apparently changed his own opinion over such a short time span.

Based on this concise review of the current orthodoxy, three standpoints regarding historical details of the Táin, best epitomized by Jackson, Carney and Byrne, can be distilled. As I personally find the arguments against Jackson's views sufficiently convincing and the infamous 'pavilions' (cf. Carney 1979: 278) need no further rehearsing here, his theory will not be entertained in this paper.

This contribution will proceed as following. Firstly, the positions of Carney and Byrne will be scrutinized to ascertain their views on historical identity of the Connachta in the Táin. It will be demonstrated that their beliefs are much closer than it is commonly appreciated and major differences can be boiled down to a 
single question of the home territory of the Uí Néill dynasty. Secondly, a comparatively recent and somewhat provocative book by Brian Lacey (2006), which covers similar ground and purports to reveal 'generally underestimated and misunderstood' influence of the Donegal kingdoms, will be addressed. Thirdly, I will present my own alternative, which could be characterized as a synthesis of Lacey's and 'the traditional view', and its implication for the saga. Conclusion will summarize the findings.

It should be stressed from outset, especially in view of controversy reignited by Lacey, that the terms "the southern Uí Néill" and "the northern Uí Néill" are used here in their modern habitual meaning. Particularly, the northern Uí Néill are understood as the ruling dynasties of the north-western corner of Ireland, amply attested through historical evidence. These terms are used out of convenience, their usage does not imply any firm stance on the true bloodlines and interrelationship of the ruling dynasties of early medieval Ireland. All these questions are beyond the scope of this contribution. Truth of the matter is that the Uí Néill are most prominent in Táin Bó Cúailnge by their absence, at least by their true name. Thus, real-life existence/ non-existence of Niall of the Nine Hostages and his extended family should not, strictly speaking, impede assessment of literary reflection of the ruling dynasties of the time in the greatest Irish saga.

\subsection{Current Consensus}

If we were to discount Carney's not overly convincing attempts at identifying real-life characters behind the cast of the Táin, comparison of his and Byrne's reasoning reveals that their positions are much closer than it may seem at first glance. Remarkable convergence on their dating has been already alluded to above.

The first scholar advocated that the Connachta of the saga should not be confused with the dynasties hailing from the modern eponymous province. In his memorable lecture on early Irish literature he suggested calling them 'the Bregians' based on their home territory (Carney 1983: 119). According to his analysis the ruling clan of the midlands counted many luminaries among their kin including Niall of the Nine Hostages himself. He envisaged the Bregians working their way from their ancestral land to the west, crossing Shannon and taking the royal site of Crúachu at some point. Those midland rulers allegedly captured Tara only around the fifth century A.D.

That theory in its unadjusted form is almost certainly wrong. Thomas CharlesEdwards in Early Christian Ireland made a convincing case that the direction of conquests in the midlands was rather from west to east. However, should we overlook this inaccuracy Carney's Bregians fit rather snugly into a modern 
definition of the southern Uí Néill. Crucially and historically accurately, Carney's Bregians did not control Tara from the start, they got there only in the early Christian period. As for the time frame of Táin Bó Cúailnge, Carney supposed its tradition is datable to 'at least century older than' 600 A.D. or, using his other circumlocution, can be assigned 'almost to the brink of the pagan period' (Carney 1983: 122). We can combine these two points stating that Carney considered that the Táin reflects warfare between the southern Uí Néill and the Ulaid around or shortly after the time when the Uí Néill captured Tara for the first time.

'The traditional view' exemplified by Byrne makes the connection between the sagas and the Uí Néill even more explicit (Byrne 2001: 51):

The sagas concentrate on the warfare between the Ulaid and the Connachta [...] But the Fifth of Ulster was finally broken up in the course of the fifth century by Niall Noígialach and his sons $[\ldots]$

Lest there be any confusion regarding author's stance on the home territory of this dynasty, he adds (Byrne 2001: 83):

\footnotetext{
The geographical distribution of the Uí Néill kingdoms and their expansion over the course of the sixth and subsequent centuries give us good reasons to agree with MacNeill as against O'Rahilly that they set out from a Connacht base. This can hardly have been other than Cruachu...
}

Thus, although superficially 'the traditional view' is different from Carney's position, both authors imply almost identical outcomes for the Táin, i.e. the text reflects the southern Uí Néill taking on the Ulaid around the fifth century. The only major difference is that Carney believed that the dynasty itself began in the territory more to the east than traditionally believed.

\subsection{Unsung Heroes of the North}

A radically different view was proposed in Lacey's Cenél Conaill and the Donegal Kingdoms. In this highly entertaining book he sought to prove that the Ulaid suffered defeat at the hands of the Donegal kingdoms, Cenél Conaill and Cenél nÉogain, which he did not consider belonging to the Uí Néill kin. He calls the very concept of the northern Uí Néill an outright 'genealogical fabrication'.

This regional history contribution received some scathing criticism, see for example Colmán Etchingham's review (2008). Despite its obvious usefulness as a travelogue of some nowadays quite obscure, but important medieval sites in Donegal the book suffers from severe methodological flaws. While all researchers are entitled to formulate hypotheses, authors are then expected to provide some evidence to confirm or refute their conjectures. Regrettably Lacey 
just indulges in progressively wilder speculation, where previous assumptions feed into new, even bolder assumptions. The resulting guesswork cannot be accepted as rigorous research because it borders on the verge of historical fiction.

Furthermore, the reader gets a strong impression that the author is not at ease with sources in pre-Modern Irish and thus is forced to rely on other researchers' translations and interpretations. As a result, other people's ideas taken out of context lead to some logical fallacies. For example, the legend of Conall Gulban, which is accorded such a prominent place in the book and forms the foundation for further elaboration, is attested only in the seventeenth-century manuscripts. Acknowledging that the editors tentatively, based on language alone, date the story to the eleventh-twelfth century, Lacey gladly reports they noted 'a mixture of archaic and modern forms'. This statement and some other hints by the editors misguide him to backdate the myth to "the very beginnings of the Cenél Conaill in the fifth or sixth century' (Lacey 2006: 34). Lacey seems to misinterpret the word 'archaic' as a licence to conveniently stretch the editors' already cautious proposal further 500 year back to the period that his book purports to cover. This makes one wonder if he is mindful of the relative meaning of this word in the context of manuscript research. Knocking down one of the central premises of Lacey's theory deals a mortal blow to much of his ensuing reasoning.

Having said all that, it should be recognized that the book raises many valid questions as well. Already half a century ago John V. Kelleher (1971) boldly suggested that the bulk of pre-eighth century regnal lists, genealogies and annals was heavily doctored to incorporate and reflect the political reality of Ireland in the eighth century, specifically the prominent position of the Uí Néill. Even previously there was no doubt among modern scholars that early portions of annals reaching the times of Christ and beyond cannot be historical. However, Kelleher wholesale put in doubt the historical accounts from the fifth, sixth and seventh century, which were deemed "safe to use" before. Lacey's work could be seen as logical continuation of Kelleher's line of thinking. He rightly notes that references to the two branches of the Uí Néill as separate entities are quite late. Also, whenever "the Uí Néill" are mentioned in the context of the sixth or seventh century, always the southern Uí Néill are understood. He is justifiably suspect of the origin legend of the northern Uí Néill based on two identically-named Niall's sons and then doubts the whole construct of the Uí Néill dynasty as springing from one progenitor. It can be no coincidence that Charles-Edwards, a distinguished scholar of early medieval Ireland, has very little to say about the origin of the northern Uí Néill and very much concentrates only on their southern "brethren" in his Early Christian Ireland.

Therefore, although Lacey's book does not resolve the queries, at least it signals serious problems with the standard historical framework. Methodological flaws of the contribution should not distract from the validity of the questions 
raised. Indeed, there is very little historically sound evidence about the beginnings of the northern Uí Néill. Their presumed kinship with the southern Uí Néill is based purely on genealogical fiction, which is demonstrably late. This leaves a window of opportunity to question the existing consensus (see above) that the Táin reflects warfare between the southern Uí Néill and the Ulaid.

\subsection{Uí Néill in Donegal}

Review of the current orthodoxy regarding the Connachta of the Ulster cycle reveals another curious detail. Notwithstanding their actual views major authors explain their position not in terms of positive evidence, but rather negative. They are adamant to stress who the Connachta were not, rather than who they were. This approach is understandable because Connaught is still a geographical reality of modern Ireland, so any reference to the tribe of the Connachta naturally evokes the modern eponymous province as a starting point. Yet it is quite clear that both Byrne and Carney were convinced that the dynasties of Connaught, at least the ones traditionally associated with Connaught, were unlikely to correspond to the Connachta of the sagas.

One way to solve this conundrum has been to recruit a dynasty that had clear connection to Connaught in early period (so could double as the Connachta of the text), but later made a clean break with their previous homeland. This was the route taken by MacNeill and Byrne and, with some caveats, by Carney. And thus was born the idea of the Uí Néill either based at Crúachnu (Byrne), or Tara (Carney) battling the Ulaid.

This neat solution had some unexpected ramifications. The scholars had to explain why and how by the time of the earliest historical sources one branch of the Uí Néill was found firmly entrenched in the modern Co. Donegal. It is quite odd for a dynasty allegedly battling with the Ulaid to the north-east of them to end up in the exactly opposite corner of Ulster. Furthermore, all evidence about expansion of the Uí Néill shows them moving to the east, presumably in search of better agricultural land and pastures. Co. Donegal is probably an epitome of all things contrary to that. Furthermore, it is perplexing how they arrived in the very north-western corner of Ireland from their presumed homeland in the centre of Ireland leaving in between lands of unrelated dynasties untouched. Byrne, a firm believer in the Uí Néill springing from Connaught, is very much conscious of this paradox (Byrne 2001: 84):

\footnotetext{
We have no trustworthy account of the actual conquest of north-west Ulster [...] but it is noteworthy that Donegal was thoroughly colonised, since we hear of few if any tributary kingdoms in this area.
} 
The last sentence of the quote neatly summarizes the biggest weakness of this theory. In all later examples of medieval Irish conquests for which we have at least some reliable evidence there are always some remnants of the previous state of affairs in the form of tributary kingdoms. This is not true in case of Co. Donegal, and the most straightforward solution to that is to accept that there was no "conquest of Donegal" to start with. It is more logical, unless new evidence of the presumed conquest is unveiled, to accept that the northern Uí Néill were indigenous to the territory. A logical implication of this conclusion would be to question the validity of genealogical connection between the two branches of the Uí Néill.

\subsection{Borders of Connaught}

Having separated two branches of the Uí Néill from each other, it is fair to ask which of the branches was doing heavy lifting of warfare against the Ulaid. Despite what the current consensus maintains and in line with Lacey's ideas, there is very little historical evidence that destruction of the kingdom of the Ulaid was wrought by the southern Uí Néill. On the contrary, almost all evidence we have points in the direction of the northern Uí Néill who fought many battles against the Ulaid progressively encroaching on their former territory. Thus, Lacey was fully warranted in trying to turn the orthodoxy on its head and prove that the real heroes of that war were to be found in the modern Co. Donegal where the northern Uí Néill expanded from.

Instead of following Lacey in his futile attempts to recruit a very late text in order to trace real kin of the northern Uí Néill, I suggest accepting that given our current state of knowledge and extant sources true origins of the northern Uí Néill may be irretrievable. It is more pertinent to try to reconcile historical reality of the northern Uí Néill fighting the Ulaid with their seemingly illogical literary label 'the Connachta' in Táin Bó Cúailnge.

A radical and ingenious solution to this puzzle is to challenge the concept of Connaught itself. Since the times of Eoin MacNeill five provinces of prehistoric Ireland became a fixture of any historical discourse and are largely taken for granted, yet the vexed question of provincial boundaries has been given rather short shrift. Many scholarly publications adhere to a silent assumption that the prehistoric provinces were largely coterminous with the modern provinces, although Ó Cróinín admits that 'no document records the names or extents of the “original” five provinces' (Ó Cróinín 2008: 187). Based on literary clues it is commonly accepted that the Fews mountains marked the southern border of Ulster and the eastern border of Connaught was marked by Shannon but beyond that the historical borders get very fuzzy. 
It is possible to retrace, at least partially, the old provincial borders by using contemporary evidence. Charles-Edwards drew attention to the fact that for Tírechán who wrote in the last decades of the seventh century 'the western region' (also labelled 'regiones Connacht' in the text) was bound not only by the Shannon, but also by the river Foyle (Charles-Edwards 2000: 37). Such description places the modern Co. Donegal firmly into province of Connaught. Curiously enough, some 250 years later Vita Tripartita "corrected" this definition moving the border of Connacht to the river Drowes (on the border of the modern Co. Sligo and Co. Donegal), undoubtedly reflecting the political development of the northern Uí Néill who no longer associated (or wanted to be associated) with Connacht (Charles-Edwards 2000: 38).

Another important piece of evidence is provided by a poem in praise of Columb Cille Fo réir Choluimb céin ad-fias, which Fergus Kelly dates to the seventh century based on linguistic features (Kelly 1973: 2). In it Columb Cille is given the usual epithet of being 'the candle of Niall [of Seven Hostages]' stressing his genealogical connection to the northern branch of Uí Néill. Strikingly the same poem in stanza 10 the poet speaks of the 'fame [of Columb Cille] on the roads of Connacht'. ${ }^{1}$ It is very difficult to explain this figure of speech, unless one assumes that in the seventh century Columb Cille was still perceived as a saint from Connaught. Due to the fact that later Columb Cille was clearly recognized as a saint from the North, this poem seems to be a rare preservation of an earlier memory.

Having demonstrated that in contemporary sources of the seventh century Co. Donegal was still perceived to be a part of Connaught, the possibility that the northern Uí Néill could feature as the Connachta in the Táin becomes not problematic at all. Paradoxically, we arrived at very similar conclusions regarding the role of the Donegal kingdoms as in Lacey's book, but through using actual seventh-century evidence rather than chasing genealogical phantoms.

\subsection{Dating the war depicted in Táin}

Having resolved the apparent puzzle of the northern Uí Néill masquerading as the Connachta in the Táin, it is worthwhile to try to apply gained insights to the vexed problem of Táin Bó Cúailnge dating. Of course, being a composite, multi-layered text the Táin obviously does not have a single "date" of creation. However, it is fair to ask whether the composition of the main story line can be assigned a post quem date based on sheer logic: if the saga reflects certain historical events, it cannot have been composed in its current form before those events occurred.

\footnotetext{
${ }^{1}$ Op. cit., 13: is iar sétaib Connacht clú, a chloth findae, fírián beóil.
} 
The traditionally assumed fifth century for the events of the Táin (see above) cannot be correct and is based, as it seems, on a spurious link between the events in the north and alleged capturing kingship of Tara by the southern Uí Néill. However, the northern Uí Néill have not expanded even outside their home base by that time, never mind seriously challenging the Ulaid's supremacy in Ulster. For example, the battle of Móin Dairi Lothair in 563 between Cruithni and the northern Uí Néill proves that the latter still did not control modern Co. Derry as late as the middle of the 6th century (Ó Cróinín 2008: 49). Additionally the traditional date is contradicted by archaeological evidence. J. P. Mallory and T. E. MacNeill in The Archaeology of Ulster place material objects mentioned in the Táin into much later period (Mallory et al 1991: 168-169):

So the story goes for any object that can be matched against the various periods of Irish archaeology. In general, it will almost never fit well into the Iron Age but rather in the later period from about the 7th to 10th centuries AD. Now this is the very period in which the tales were written down.

As Emain Macha is located in the territory of Argíalla, a literary depiction of allIreland assault on the capital of the Ulaid fits best with the period when the northern Uí Néill battled over control of Argíalla. It is commonly accepted that it took the great battle of Mag Roth (Moira, Co. Down) in 637 for the northern Uí Néill to defeat the Ulaid decisively and establish their unchallenged supremacy over Argíalla (Ó Cróinín 2008: 51). Therefore, it could be tentatively suggested that the main story line of the Táin was inspired by this very battle of events leading to it placing creation of the story as late as the middle of the seventh century or thereafter.

\section{Concluding remarks}

In this article I have reviewed the current orthodoxy regarding the identity of the Connachta in Táin Bó Cúailnge. Even seemingly contrary schools of thought, despite their differences, converge on the theory that the saga reflects warfare between the southern Uí Néill and the Ulaid in the fifth century AD. Agreeing with Lacey, but for completely different reasons, I find this view untenable as it contradicts existing historical evidence. The northern Uí Néill are more likely candidates for the role of the Connachta in the Táin. Apparent inconsistency of terminology is resolved through demonstrating that the modern pre-conceptions of the provincial boundaries is misleading and do not apply to the early medieval period. It is tentatively suggested that the main story line of the saga was inspired by the battle of Mag Roth, placing creation of the epic at least as late as the middle of the seventh century. 


\section{REFERENCES}

Byrne, Francis John. 2001. Irish kings and high-kings. Dublin: Four Courts Press.

Carney, James. 1979. Studies in Irish literature and history. Dublin: DIAS.

Carney, James. 1983. Early Irish literature: the state of research. In Gearóid Mac Eoin, Anders Ahlqvist and Donncha Ó hAodha (eds.). Proceedings of the Sixth international congress of Celtic studies held in University College, Galway 6-13 July 1979, 113-130. Dublin.

Charles-Edwards, Thomas. 2000. Early Christian Ireland. Cambridge: Cambridge University Press.

Kelly, Fergus. 1973. A Poem in Praise of Columb Cille. Ériu 24. 1-34.

Lacey, Brian. 2006. Cenél Conaill and the Donegal kingdoms. Dublin / Portland: Four Courts Press. Mallory, James Patrick and Thomas MacNeill. 1991. The archaelogy of Ulster from colonization to plantation. Belfast: The Institute of Irish Studies, Queen's University of Belfast.

Ó Cróinín, Dáibhí. 2008. Ireland, 400-800. In Dáibhí Ó Cróinín (ed.). A New History of Ireland (vol. 1). Prehistoric and Early Ireland, 182-234. Oxford: Oxford University Press.

Ó hUiginn, Ruairí. 1990. The literature of the Laigin. Emania 7. 5-9.

Ó hUiginn, Ruairí. 1992. The background and development of Táin Bó Cúailnge. In J. P. Mallory (ed.). Aspects of the Táin, 29-67. Belfast. 